\title{
PERAN MANGIFERIN SEBAGAI INHIBITOR ENZIM KOLAGENASE DAN ELASTASE
}

\author{
Devi Maulina \\ Maulinadevi2011@gmail.com, Politeknik Kesehatan Hermina
}

\begin{abstract}
Reactive Oxygen Species (ROS) cause aging by eliminating skin elasticity. It is caused by wrinkles, sagging, and pigmentation. ROS can increase the expression of proteinase enzymes such as matrix metalloproteinases (MMPs) and serine proteases. These enzymes are responsible for degrading collagen and elastin, which are protein components in the extracellular matrix (ECM) that play a role in supporting the structure and physical properties of the skin. Mangiferin activity was proven as an antioxidant by reducing excess ROS in cells. This study is a literature review of the role of mangiferin in inhibiting collagenase and elastase enzymes that cause collagen and elastin damage to prevent aging.
\end{abstract}

Keywords: mangiferin, antiaging, collagenase inhibitor, elastase inhibitor.

\begin{abstract}
Abstrak
Reactive Oxygen Species (ROS) mampu menyebabkan penuaan dini dengan cara menghilangkan elastisitas kulit sehingga kulit menjadi keriput, kendur,dan mengalami pigmentasi. ROS dapat meningkatkan ekspresi enzimenzim proteinase seperti matriks metaloproteinase (MMPs) dan protease serin. Enzim tersebut bertanggung jawab dalam mendegradasi kolagen dan elastin yang merupakan komponen protein dalam matriks ekstraselular (ECM) yang berperan dalam menunjang struktur dan sifat fisik kulit. Mangiferin telah terbukti aktivitasnya sebagai antioksidan dengan mengurangi kelebihan ROS didalam sel. Penelitian ini merupakan literatur review peran mangiferin menghambat kerja enzim kolagenase dan elastase yang menyebabkan kerusakan kolagen dan elastin sehingga tanda tanda penuaan dapat dicegah.
\end{abstract}

Kata kunci: mangiferin, antiaging, inhibitor kolagenase, inhibitor elastase.

\section{PENDAHULUAN}

Penuaan pada kulit merupakan suatu proses biologis yang kompleks. Prosespenuaan kulit dapat dibagi menjadi dua kategori yaitu penuaan intrinsik danekstrinsik. Penuaan kulit intrinsik atau penuaan alami disebabkan oleh perubahan elastisitas kulit yang terjadi seiring dengan bertambahnya usia. Penuaan jenis ini tidak dapat dicegah. Sedangkan penuaan kulit ekstrinsik disebabkan karena faktor lingkungan seperti paparan radiasi matahari (photoaging) (Jenkins, 2002). Paparan sinar ultraviolet menyebabkan perubahan fisik pada kulit akibat adanya perubahan yang terjadi padajaringan ikat melalui pembentukan lipid peroksida, perubahan komposisi sel, aktivitas enzim dan Reactive Oxygen Species (ROS) (Aslam et al., 2006; Jenkins, 2002).

ROS dikaitkan dengan perannya yang mampu menyebabkan penuaan dini dengan cara menghilangkan elastisitas kulit sehingga kulit menjadi keriput, kendur, dan mengalami pigmentasi. ROS dapat meningkatkan ekspresi enzim-enzim proteinase seperti matriks metaloproteinase (MMPs) dan protease serin. Enzim tersebut bertanggung jawab dalam mendegradasi kolagen dan elastin yang merupakan komponen protein dalam matriks ekstraselular (ECM) yang berperan dalam menunjang struktur dan sifat fisik kulit. MMPs adalah endopeptidase yang mengandung seng ( $\mathrm{Zn}$ ) yang meliputi kolagenase dan gelatinase. Kolagenase adalah metaloproteinase yang mampu memecah molekul lain yang ditemukan di dalam sel. Kolagenase-2 (MMP-8) misalnya, dapat membelah aggrecan, elastin, fibronektin, gelatin dan laminin serta kolagen. Sistem proteolitik lain yang terlibatdalam degradasi ECM adalah elastase yang merupakan protease serin yang bertanggung jawab terutama untuk pemecahan elastin. Elastase juga mampu memecah kolagen, fibronektin dan protein ECM lainnya (Kacem, 2013).

Cara untuk memperlambat proses penuaan dini pada kulit adalah dengan menggunakan 
zat kimia atau bahan alami yang dapat menangkal ROS. Sebagai bahan penghambat penuaan dini, bahan-bahan ini seharusnya tidak hanya berfungsi sebagai radio proteksi saja tetapi harus mampu menembus ke dermis dan untuk menghambat aktivasi dan aktivitas enzim ECM terutama enzim kolagenase danelastase. Dalam beberapa tahun terakhir, minat terhadap senyawa aktif dari bahan alam yang toksisitasnya rendah tetapi memiliki efek farmakologis telah meningkat. Molekul yang diperoleh dari tanaman digunakan sebagai sumber zat pelindung terhadap stres oksidatif. Kandidat yang akan digunakan dalam aktivitas tersebut adalah mangiferin.

Mangiferin (2-C- $\beta$-D-glucopyranosyl-1,3,6,7-tetrahydroxyxanthone) adalah senyawa polifenol yang memiliki sifat antioksidan yang kuat. Mangiferin diperoleh dari tanaman mangga (Mangifera indica L., Anacardiaceae). Mangiferin telah terbukti memiliki banyak aktivitas farmakologi. Penelitian sebelumnya telah membuktikan bahwa mangiferin memiliki aktivitas sitotoksik terhadap berbagai sel tumor (Gold-Smith et al., 2016). Mangiferin dapat menginduksi apoptosissel leukimia myeloid akut pada manusia (HL-60) (Shoji et al., 2011). Mangiferin dapat meningkatkan apoptosis hesperidin yang terdapat pada sel adenokarsinoma serviks pada manusia (HeLa) (Bartoszewski et al., 2014). Di sisi lain, uji toksisitas akut dan subkronik mangiferin pada hewan pengerat tidak menunjukkan toksik (Prado et al., 2015).

Aktivitas antioksidan mangiferin telah banyak diteliti (Ferreira et al., 2013; Stoilova et al., 2008). Tetapi penelitian tentang peran mangiferin terhadap penghambatan aktivitas enzim kolagenase dan elastase belum pernah di ulas sebelumnya. Sehingga dalam literarur review ini akan mengulas mengenai peran mangiferin sebagai penghambat enzim kolagenase dan elastase.

\section{METODE}

Penelitian ini merupakan literatur review mengenai peran mangiferin sebagai inhibitor enzim kolegenase dan elastase yang bertanggung jawab pada terjadi nya penuaan. Data diperoleh dari penelusuran literatur dengan cara pengumpulan literature dari database seperti Scopus, Pubmed, Google Scholar dan Science Direct dari tahun 2002-2017.

\section{PEMBAHASAN}

\section{Mekanisme Molekuler Penuaan Intrinsik}

Proses penuaan intrinsik mirip dengan yang terjadi di sebagian besar organinternal yaitu dengan kerusakan fungsi jaringan secara lambat namun pasti. Pada jenis penuaan ini stratum korneum relatif tidak berubah, namun epidermis dan dermis menipis. Terjadi juga pengurangan jumlah dan kapasitas biosintesis fibroblas dan hilangnya elastisitas jaringan dermis papiler secara progresif. Kandungan kolagen kulit menurun seiring bertambahnya usia dan serat kolagen yang semula halus menjadi semakin padat dan rapat. Proses penuaan kulit intrinsik diperkirakan disebabkan karena adanya penurunan kapasitas proliferasi sel-sel kulit, penurunan sintesis matriks pada lapisan dermis; dan peningkatan ekspresi enzim yang dapat merusak matriks ekstraseluler (Jenkins, 2002).

Penuaan pada tingkat seluler melibatkan penahanan terhadap pertumbuhansel pada fase G1 ketika sel mencapai tahap akhir replikasi . Sel-sel yang mengalamipenuaan tidak dapat dirangsang oleh mitogen fisiologis untuk memasuki fase S1. Penurunan pertumbuhan terkait usia ini sebagian dapat terjadi karena adanya represi selektif beberapa gen pengatur pertumbuhan yang ekspresinya penting untuk perkembangan G1 dan sintesis DNA. Contohnya pada fibroblas, gen yang mengalami represis meliputi c-fos proto-oncogene, gen Id-1 and Id-2, dan faktor transkirpsi E2F yang semuanya diregulasi dalam fibroblas senescent. Regulator pertumbuhan negatif juga diekspresikan secara berlebihan termasuk penghambat p21 dan p16 dari protein kinase yang bergantung siklin (Jenkins, 2002).

Perubahan lain yang terlihat pada penuaan fibroblas kulit adalah terjadi peningkatan 
ekspresi IL-1 $\alpha$ dan EGF-like-cytokine-heregulin yang memodulasi pertumbuhan dan diferensiasi payudara dan sel epitel lainnya. Ikatan EGF dengan reseptor terfosforilasi berkurang dan dianggap sebagai hasil perubahan terkait usiapada elemen persinyalan yang penting. Perubahan lain yang dilaporkan mencakuppeningkatan ekspresi antagonis reseptor IL1 dan diferensiasi yang terkait dengan SPR2 (Jenkins, 2002).

Penurunan fungsi jaringan dan integritas yang menjadi ciri penuaan, karenaterjadi perubahan dalam diferensiasi seluler berupa perubahan ekspresi matriks ekstraseluler dan enzim metaloproteinase. Pada fibroblas dermal normal aktivitas metalloproteinase seperti kollagenase (MMP1) relatif rendah sedangkan inhibitor metalloproteinase (TIMP1) tinggi sehingga mengurangi proses degradasi matriks ekstraseluler. Sebaliknya, pada proses penuaan terjadi peningkatan kollagenase dan penurunan TIMP1. Seiring dengan perubahan ini laju biosintesis kolagen juga turunsecara signifikan pada kulit orang tua dibanding dengan jaringan janin atau selama awal tahun pasca kelahiran. Perubahan ini akan berkontribusi pada pengurangan dan disorganisasi kolagen umumnya terkait dengan penuaan kulit dan atrofi kulit secara keseluruhan (Jenkins, 2002)

Ekspresi gen elastin juga secara nyata berkurang setelah usia 40-50 tahun dan jaringan elastin di lapisan dermis hilang secara progresif menyebabkan kulit kehilangan elastisitasnya sehingga tidak mampu kembali seperti semula yang merupakan ciri dari penuaan lainnya(Jenkins, 2002)

Teori radikal bebas juga diyakini menjadi penyebab penuaan intrinsik. Teori ini menunjukkan bahwa penuaan sangat dipengaruhi radikal bebas ROS yang dapatmempengaruhi faktor genetik melalui modulasi gen. ROS dapat menyebabkan kerusakan lipid, protein dan DNA dengan cara merusak molekul yang elektronnyaditarik oleh ROS tersebut sehingga menyebabkan kerusakan sel, gangguan fungsi sel, bahkan kematian sel (Jenkins, 2002).

\section{Mekanisme Molekuler Penuaan Ekstrinsik}

Penuaan ekstrinsik terutama diakibatkan oleh paparan sinar ultraviolet. Paparan kronis kulit manusia dengan sinar UV mempengaruhi struktur dan fungsi kulit. Kerusakan sangat tergantung dari jumlah dan jenis sinar UV dan juga tipe kulit seseorang. Radiasi sinar UV mengakibatkan sunburn, imunosupresi, stress oksidatif, dan kanker kulit menyerupai penuaan dini kulit maka disebut photoaging.Photoaging merupakan akumulasi kerusakan akibat paparan kronis sinar matahari.Photoaging terjadi sebagai akibat kerusakan kumulatif dari radiasi UV. Radiasi UV(dengan panjang gelombang 100-400 $\mathrm{nm}$ ) merupakan 5\% dari seluruh kisaran radiasi sinar matahari. Secara umum dibagi menjadi 3, yaitu UV A (320-400 nm), UV B (280$320 \mathrm{~nm})$, dan UV C (100-280 nm). UV C terabsorbsi langsung oleh lapisan ozone di atmosfer. Radiasi UV mengaktivasi reseptor permukaan sel yang mengakibatkan propagasi sinyal intraseluler dan sintesis faktor transkripsi, protein inti yang berikatan dengan DNA untuk meningkatkan atau menekan gen transkripsi. Satu faktor transkripsi yang secara cepat terinduksi oleh radiasi UV adalah AP-1. AP-1 mempengaruhi gen transkripsi kolagen pada fibroblas, menurunkan level prokolagen I dan III, selain itu AP-1 merangsang gen transkripsi yang mengkode matrix-degrading enzyme seperti metalloproteinase. Pada kulit yang mengalami photoaging tersebut dapat memperlihatkan gambaran klinis permukaan kasar, bernodus, kerutan halus dan kasar. bercak kekuningan, dan kering (Wahyuningsih, 2011)

Ketika radiasi sinar ultraviolet yang terdapat pada sinar matahari menyentuh kulit, sebagian disebarkan dan dipantulkan pada stratum korneun, sebagian ditransmisikan. Kedalaman penetrasinya tergantung panjang gelombang. Sinar UVA dan UV B merupakan spektrum cahaya matahari yang berperan pada proses photoaging ini. Walaupun UV B (290$320 \mathrm{~nm}$ ) memiliki panjang gelombang yang lebih pendek tetapi lebih efisien mencapai permukaan bumi, lebih kuat terserap pada epidermis dan lebih eritemogenik dibandingkan dengan UV A. Terbentuknya Reactive Oxygen Species (ROS) selama paparan berulang UV B 
menurunkan ekspresi enzim antioksidan dan meningkatkan modifikasi protein oksidatif dan akumulasi peroksidasi lipid dan produk glikasi. Reactive oxygen species yang terbentuk selama pajanan UV menghambat transforming growth factor (TGF)- $\beta$ sehingga produksi kolagen terhambat serta meningkatkan faktor transkripsi AP-1 yang selanjutnya meningkatkan produksi matriks kolagenase yang merupakan enzim yang mendegradasi kolagen. Penelitian biokimia menunjukkan pada photoaging terjadi perubahan jaringan ikat yang berupa penurunan prekursor kolagen tipe I dan III, cross link, peningkatan rasio kolagen tipe III dan I, peningkatan elastin. Perubahan pada matriks ekstraseluler dermis tersebut yang mengakibatkan gambaran klinis pada photoaging, yang ditandai dengan kerutan, perubahan pigmentasi, dan hilangnya tonus kulit (Wahyuningsih, 2011).

\section{Mekanisme Mangiferin Sebagai Penghambat Kolagenase dan Elastase}

Mangiferin menghambat aktivitas elastase dan kolagenase secara reversibel, disebut sebagai penghambatan non-kompetitif. Mangiferin berinteraksi dengan bentuk bebas enzim kolagenase pada lokasi diluar situs aktif dan berinteraksi juga dengan kompleks enzim-substrat. Mangiferin maupun metabolitnya yang berupa o-quinone yang bersifat sebagai chelating agen mampu berikatan dengan $\mathrm{Ca}^{2+}$ dan $\mathrm{Zn}^{2+}$ yang merupakan co-factor dari enzim kolagenase sehingga menghambat aktivitas katalitik enzim kolagenase. Menurut penelitian yang dilakukan oleh Ochocka dkk, mangiferin terbukti dapat menembus lapisan stratum korneum karena karakteristiknya dengan $\log \mathrm{P}$ diantara 1-3 yaitu (mangiferin $\log \mathrm{P}=2.73$ ), dan berat molekulnya yang kurang dari $500 \mathrm{Da}(\mathrm{BM}$ mangiferin $=422.34 \mathrm{Da})$ dan mampu menghambat aktivitas enzim kolagenase dengan $\mathrm{IC}_{50}$ sebesar $253.57 \pm 7.56 \mu \mathrm{M}$. Diharapkan dengan penghambatan aktivitas kolagenase maka serat kolagen di dalam lapisan dermis akan memberikan fungsi yang maksimal sebagai pembentuk dukungan struktural dan kekuatan otot dan tulang. Juga menciptakan elastisitas bagi kulit dan memberikan kontribusi untuk pengembangan pertumbuhan sel baru untuk menggantikan yang lama dan sel-sel mati (Ochocka et al., 2017).

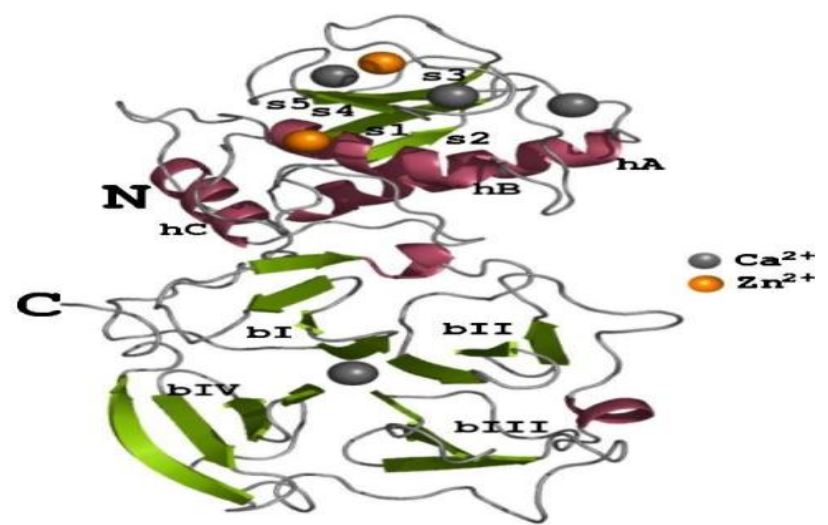

Gambar 1. Struktur Enzim Kolagenase (Iyer et al., 2006)

Mangiferin dapat berikatan dengan enzim elastase dengan membentukikatan kovalen dengan situs aktif Ser195 sehingga menghambat aktivitas katalitik enzim elastase. Mangiferin dapat menghambat aktivitas enzim elastase dengan $\mathrm{IC}_{50}$ sebesar $139.64 \pm 9.34 \mu \mathrm{M}$. Diharapkan dengan penghambatan aktivitas elastase maka serat elastin di dalam lapisan dermis akan memberikan fungsi yang maksimal terhadap elastisitas kulit sehingga kulit menjadi lebih kenyal dan tidak keriput (Ochocka et al., 2017). 


\section{Indonesian Journal of Health Science}

Volume 1 No. 1, Juni 2021

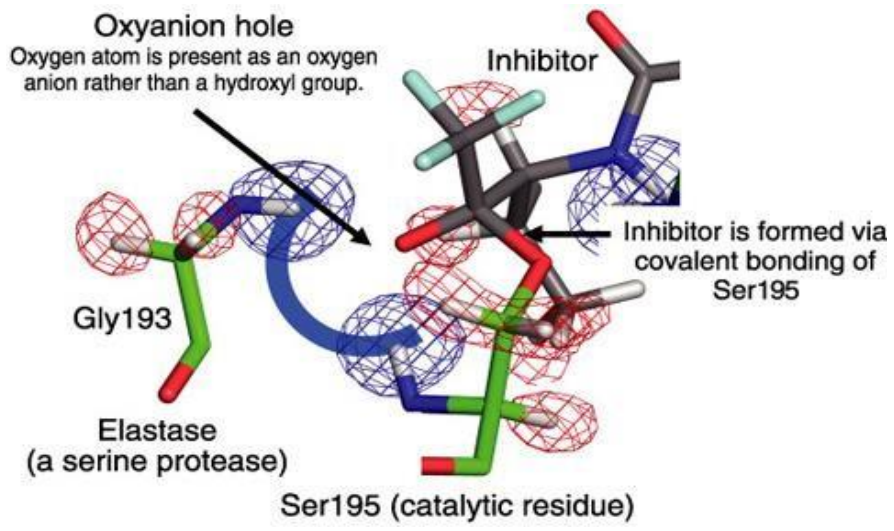

Gambar 2. Struktur Enzim Elastase (Tamada et al., 2009)

Aktivitas mangiferin sebagai antioksidan juga dapat mencegah penuaan intrinsik yang disebabkan oleh ROS melalui mekanisme sebagai berikut:

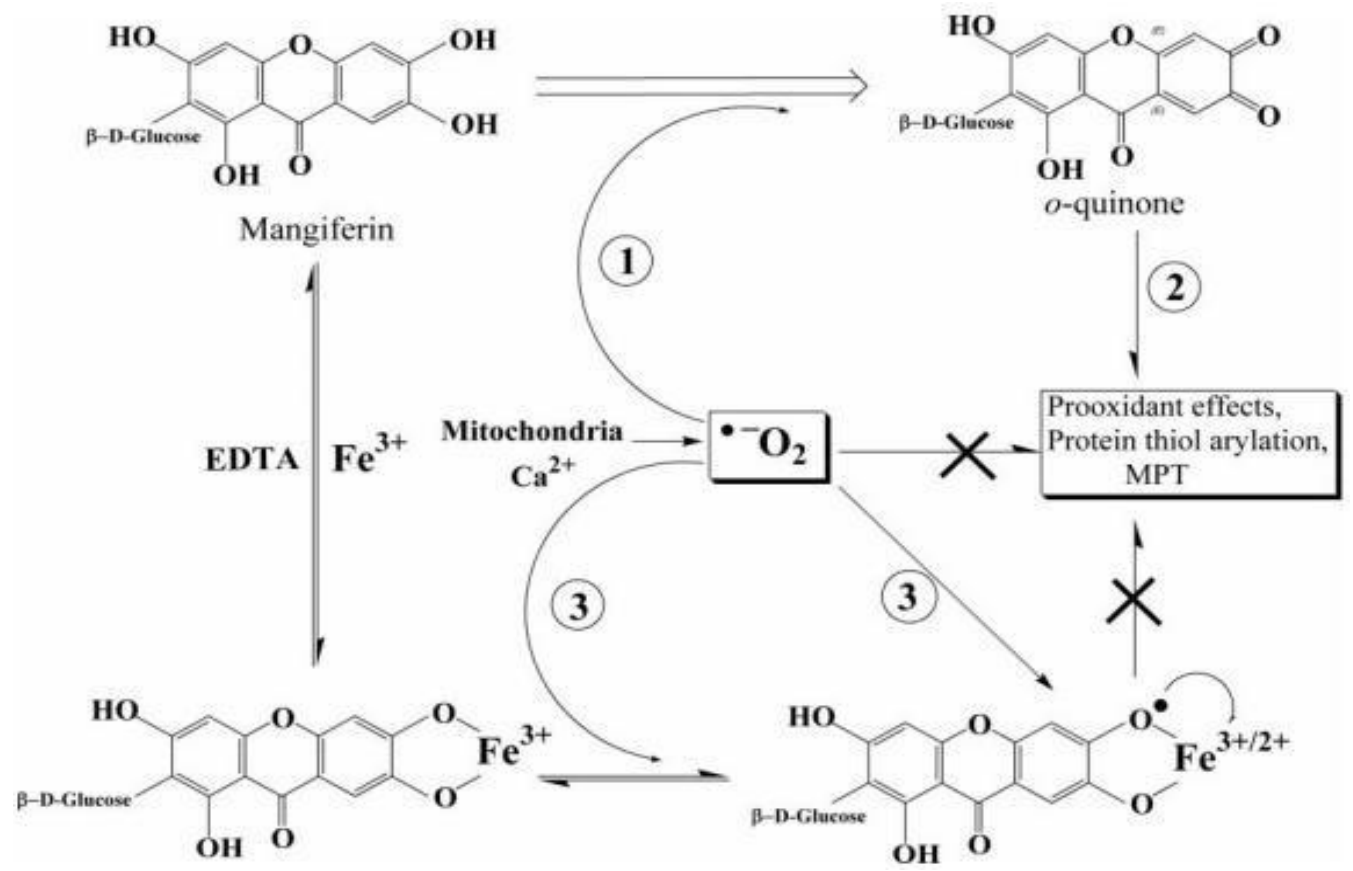

Gambar 3. Reaksi mangiferin menghambat ROS dan logam (Pardo-Andreu et al., 2007)

Radikal superoksida yang terbentuk akibat stress oksidatif yang terjadi karena level $\mathrm{Ca}^{2+}$ menigkat di mitokondria atau beberapa kondisi lain akan dinetralkan oleh mangiferin catechol moiety. Mangiferin akan teroksidasi dan membentuk metabolit kuinon/kuinon metida yang mempunyai kemampuan mengarilasi protein thiol di mitokondria. Koordinasi Fe(III) pada gugus katekol mangiferin akan meningkatkan aktivitasnya sebagai radical scavenger terhadap ROS sehingga mencegah terjdinya mitochondrial swelling (Pardo-Andreu et al., 2007).

\section{DAFTAR PUSTAKA}

Aslam, M. N., Lansky, E. P., \& Varani, J. (2006). Pomegranate as a cosmeceutical source: Pomegranate fractions promote proliferation and procollagen synthesis and inhibit matrix metalloproteinase-1 production in human skin cells. Journal of Ethnopharmacology, 103(3), 311-318. https://doi.org/10.1016/j.jep.2005.07.027 
Bartoszewski, R., Hering, A., Marszałł, M., Hajduk, J. S., Bartoszewska, S., Kapoor, N., Kochan, K., \& Ochocka, R. (2014). Mangiferin has an additive effect on the apoptotic properties of hesperidin in Cyclopia sp. tea extracts. PLoS ONE, 9(3). https://doi.org/10.1371/journal.pone.0092128

Ferreira, F. da R., Valentim, I. B., Ramones, E. L. C., Trevisan, M. T. S., Olea-Azar, C., PerezCruz, F., de Abreu, F. C., \& Goulart, M. O. F. (2013). Antioxidant activity of the mangiferin inclusion complex with $\beta$-cyclodextrin. LWT - Food Science and Technology, 51(1), 129-134. https://doi.org/10.1016/j.lwt.2012.09.032

Gold-Smith, F., Fernandez, A., \& Bishop, K. (2016). Mangiferin and cancer: Mechanisms of action. Nutrients, 8(7), 16-20. https://doi.org/10.3390/nu8070396

Iyer, S., Visse, R., Nagase, H., \& Acharya, K. R. (2006). Crystal Structure of an Active Form of Human MMP-1. Journal of Molecular Biology, 362(1), 78-88. https://doi.org/10.1016/j.jmb.2006.06.079

Jenkins, G. (2002). Molecular mechanisms of skin ageing. Mechanisms of Ageing and Development, 123(7), 801-810. https://doi.org/10.1016/S0047-6374(01)00425-0

Kacem, R. (2013). Phenolic compounds from medicinal plants as Natural anti-elastase products for the therapy of pulmonary emphysema. Journal of Medicinal Plants Research, 7(48), 3499-3507. https://doi.org/10.5897/JMPR12.865

Ochocka, R., Hering, A., Stefanowicz-Hajduk, J., Cal, K., \& Barańska, H. (2017). The effect of mangiferin on skin: Penetration, permeation and inhibition of ECM enzymes. PLoS ONE, 12(7), 1-16. https://doi.org/10.1371/journal.pone.0181542

Pardo-Andreu, G. L., Cavalheiro, R. A., Dorta, D. J., Naal, Z., Delgado, R., Vercesi, A. E., \& Curti, C. (2007). Fe(III) shifts the mitochondria permeability transition-eliciting capacity of mangiferin to protection of organelle. Journal of Pharmacology and Experimental Therapeutics, 320(2), 646-653. https://doi.org/10.1124/jpet.106.112003

Prado, Y., Merino, N., Acosta, J., Herrera, J. A., Luque, Y., Hernández, I., Prado, E., Garrido, G., Delgado, R., \& Rodeiro, I. (2015). Acute and 28-day subchronic toxicity studies of mangiferin, a glucosyl xanthone isolated from mangifera indica 1. Stem bark. Journal of Pharmacy and Pharmacognosy Research, 3(1), 13-23.

Shoji, K., Tsubaki, M., Yamazoe, Y., Satou, T., Itoh, T., Kidera, Y., Tanimori, Y., Yanae, M., Matsuda, H., Taga, A., Nakamura, H., \& Nishida, S. (2011). Mangiferin induces apoptosis by suppressing Bcl-xL and XIAP expressions and nuclear entry of NF- $\mathrm{kB}$ in HL-60 cells. Archives of Pharmacal Research, 34(3), 469-475. https://doi.org/10.1007/s12272-011-0316-8

Stoilova, I., Jirovetz, L., Stoyanova, A., Krastanov, A., Gargova, S., \& Ho, L. (2008). Antioxidant activity of the polyphenol mangiferin. Electronic Journal of Environmental, Agricultural and Food Chemistry, 7(2), 2706-2716.

Tamada, T., Kinoshita, T., Kurihara, K., Adachi, M., Ohhara, T., Imai, K., Kuroki, R., \& Tada, T. (2009). Combined high-resolution neutron and X-ray analysis of inhibited elastase confirms the active-site oxyanion hole but rules against a low-barrier hydrogen bond. Journal of the American Chemical Society, 131(31), 11033-11040. https://doi.org/10.1021/ja9028846

Wahyuningsih, K. A. (2011). Astaxanthin Memberikan Efek Proteksi Terhadap Photoaging. Journal of Medicine, 10(3), 149-160. 